\title{
Pandangan Etika Kristen Terhadap Identitas Homoseksual
}

\author{
Christopher Alexander \\ Sekolah Tinggi Teologi Kharisma Bandung \\ CAlexander.CA26@gmail.com \\ Ferry Simanjuntak \\ Sekolah Tinggi Teologi Kharisma Bandung \\ ferrysimanjuntak76@gmail.com
}

\begin{abstract}
Abstrak
Persoalan mengenai homoseksualitas terus menjadi perdebatan di berbagai kalangan, baik dalam psikologi, biologi, maupun teologi. Berbagai argumen saling dilontarkan untuk mempertahankan pandangan masing-masing pihak pro dan kontra homoseksualitas. Terlebih lagi persoalan mengenai identitas homoseksual. Gay gene adalah senjata paling utama yang dilontarkan oleh pihak pro homoseksual untuk menjadi tembok pelindung bagi para kaum homoseksual. Pembenaran diri mengenai homoseksualitas pun turut didukung dengan cara menggunakan Alkitab sebagai pendukungnya. Dalam kesempatan kali ini, penulis mengangkat topik "Pandangan Etika Kristen Terhadap Identitas Homoseksual" untuk mencoba menolong setiap kaum homoseksual untuk menyadari bahwa mereka tidak pernah diciptakan dalam keadaan seperti itu. Penulis menggunakan metode penelitian berupa studi pustaka dengan cara mengangkat argumen-argumen serta sanggahansanggahan yang penulis ambil dari berbagai literatur yang ada. Dan Alkitab jelas mengatakan bahwa menjadi homoseksual adalah dosa (Roma 1:24-27). Allah tidak pernah menciptakan seseorang dengan orientasi seksual berupa homoseksual, terbukti dengan Allah menciptakan Adam dan Hawa sejak mulanya, yang berarti orientasi seksual yang dikehendaki Allah adalah berupa heteroseksual. Para kaum homoseksual kemudian harus mengakui dosanya di hadapan Allah, bertobat, dan meminta kasih karunia Allah untuk memampukan mereka keluar dari dosa homoseksualitas. Karena pengampunan dan kasih karunia Allah selalu tersedia bagi mereka yang mau merendahkan hatinya untuk datang kepada-Nya.
\end{abstract}

Kata Kunci: Etika Kristen; Homoseksualitas; Identitas Homoseksual; Gen Gay; Genetik 


\section{PENDAHULUAN}

Homoseksual merupakan salah satu dari tiga orientasi seksual yang ada pada diri manusia (dua yang lainnya adalah heteroseksual dan biseksual), dimana homoseksual merupakan ketertarikan seseorang secara seksual kepada orang yang memiliki jenis kelamin yang sama. Perempuan yang tertarik pada perempuan dikenal dengan istilah lesbian, sedangkan laki-laki yang tertarik pada laki-laki dikenal dengan istilah gay (Mastuti et al., 2012: 194).

Berdasarkan hasil survey CIA yang dimuat oleh six pack magazine.net, Indonesia menempati peringkat kelima sebagai negara yang menyumbang penyebaran LGBT (Lesbi, Gay, Bisexual, Transgender) setelah China, Eropa, India, dan Amerika. Sejumlah lembaga survey independen luar dan dalam negeri menyebutkan bahwa Indonesia memiliki populasi LBGT sebesar 3\% atau setara dengan 7,5 juta dari 250 juta penduduk Indonesia. Pada tahun 2012, Kementrian Kesehatan mengestimasikan terdapat 1.095 .970 homo atau gay yang diistilahkan dengan LSL (laki-laki seks dengan laki-laki). Dan lebih dari 5\% atau sejumlah 66.180 orang menjadi pengidap HIV akibat perilaku seks yang dilakukan (Hasnah \& Alang, 2019: 64).

Mengutip Annida (2003), mengatakan bahwa homoseksual dari sudut pandang psikologis dianggap sebagai sebuah tindakan yang abnormal, gangguan mental, bahkan kelainan perilaku seksual yang secara moral tidak dapat diterima oleh masyarakat (Veritasia, 2014: 274).

Isu-isu mengenai homoseksual bermunculan dan tengah menjadi pembahasan di kalangan masyarakat awam dan juga ilmiah. Perbincangan mengenai homoseksual ini bertambah mencolok dengan munculnya peristiwa pernyataan diri sebagai homoseksual yang dikenal dengan istilah "coming out" (Gozan, 2016: 75).

King, seperti yang dikutip oleh Rahardjo, menyebutkan bahwa ada empat fase coming out yang dialami oleh kaum homoseksual. Pertama, recognition of being homosexual yaitu fase di mana mereka merasa kebingungan, merasa sepi dan sendiri, juga merasa tak nyaman. Kedua, getting to know other homosexual - yaitu fase di mana mereka mencoba untuk menemukan siapa orang-orang di sekitar mereka 
yang juga merupakan seorang homoseksual dan berusaha membangun relasi dengan kaum homoseksual lainnya. Ketiga, telling family and friends - yaitu fase di mana mereka jujur dan terbuka kepada keluarga dekat dan sahabatsahabat mereka mengenai identitas seksual mereka dalam rangka agar mendapatkan dukungan sosial. Keempat, complete openness - yaitu tahapan di mana mereka berusaha untuk membuka diri terhadap semua orang, baik teman kerja atau pun teman kuliah, dan sebagainya, untuk memperoleh acceptance dari orangorang secara utuh mengenai orientasi dan identitas seksual mereka apa pun itu (Rahardjo, 2007: 91).

Alasan yang dikemukakan oleh para kaum homoseksual ini adalah faktor genetik, yang kemudian membentuk identitas mereka sebagai seorang homoseks (entah itu gay atau pun lesbian). Mereka pada umumnya percaya bahwa perilaku homoseksual ini didorong oleh sebuah faktor, yaitu faktor genetik dalam diri seseorang, sehingga kemudian mereka merasa bahwa mereka terlahir dan tercipta dengan keadaan orientasi seksual berupa homoseksual. (Gozan, 2016: 76).

Oleh karena itu, pada kesempatan kali ini, penulis menganggap perlu untuk menyatakan pandangan Etika Kristen terhadap identitas homoseksual. Penulis akan memaparkan beberapa argumen yang penulis ambil dari sudut pandang secara biologis, psikologis, dan teologis mengenai identitas homoseksual ini.

\section{METODE PENELITIAN}

Metode yang penulis gunakan untuk melaksanakan penelitian ini adalah metode studi pustaka (library research). Studi pustaka dapat diartikan sebagai suatu studi yang digunakan dalam metode pengumpulan data pustaka dengan bantuan berbagai jenis material seperti dokumen, buku, jurnal, majalah, dan sebagainya (Mirzaqon, 2018: 3). Pertama-tama, penulis akan mengangkat argumen-argumen yang dilontarkan oleh kaum pendukung homoseksual mengenai identitas homoseksual. Kemudian penulis akan memberikan sanggahan mengenai argumen-argumen tersebut dari sudut pandang biologi, psikologi dan teologi yang akan penulis ambil dari 
DIEGESIS: Jurnal Teologi

Volume 6 No. 1, Februari 2021 Hlm 70-88

berbagai literatur yang ada untuk menyatakan pandangan Etika Kristen terhadap identitas homoseksual.

\section{HASIL DAN PEMBAHASAN}

Pertanyaan yang sering muncul mengenai homoseksualitas adalah bagaimana dan mengapa seseorang bisa memiliki orientasi seksual berupa homoseksual. Banyak pandangan mulai bermunculan tidak hanya dari segi psikologi dan biologi, namun juga muncul dari kalangan orang Kristen (segi teologi). Di luar sana, khususnya dalam dunia kekristenan di Barat, ada banyak orang-orang yang berusaha menggunakan Alkitab sebagai pendukung untuk melegalkan hubungan homoseksual. Untuk membahas hal itu, penulis akan mencoba membagi-bagikan pembahasannya menjadi beberapa bagian, seperti sebagai berikut.

\section{Sudut Pandang Psikologi: Identitas}

\section{Homoseksual}

Hidayah, dalam hasil
penelitiannya, menemukan pola
dinamika orientasi seksual pada kaum
gay. Kemudian ia merumuskan
bahwa adanya perilaku gay
responden diawali dengan adanya

pola asuh yang salah di dalam keluarganya, dalam hal ini responden lebih dekat dengan ibunya dibandingkan dengan ayahnya, bahkan ia cenderung tidak menyukai ayahnya (Hidayah, 2019: 130). Lebih lanjut lagi, Hidayah mengutip Albert Bandura yang menuturkan bahwa apa yang dipikirkan seseorang akan mempengaruhi perilakunya, dan perilaku yang timbul akan menghasilkan reaksi dari orang lain. Ini merupakan sebuah gambaran ketika sang orang tua memberikan pola asuh serta pemikiran yang salah, juga ditambah dengan kondisi lingkungan keluarga yang buruk terhadap anak, maka anak akan cenderung mengeluarkan perilaku maladaptif (Hidayah, 2019: 130).

Selain dari segi pola asuh, Hidayah juga mendapati bahwa adanya peniruan (modelling) yang dilakukan oleh responden serta teman-temannya setelah menonton blue film. Glassman mengungkapkan teori mengenai perkembangan sosial kognitif, yang menunjukkan sebagian besar dari apa yang dipelajari seseorang didasarkan pada pengamatan seseorang terhadap perilaku orang lain, bukan pengalaman langsung dan penguatan. 
Jadi, paparan dari perilaku yang ada dalam blue film yang juga salah dipraktekkan oleh responden beserta teman-temannya, kemungkinan besar akan meningkatkan perilaku maladaptif si pengamat. (Hidayah, 2019: 130).

Juga didapati adanya trauma berupa kekecewaan yang dialami oleh responden terhadap perempuan. Hal ini berdampak kepada perubahan pola pikir, perilaku dan kesehatan. Terlebih lagi dengan adanya satu titik berat yang menyebabkan responden menjadi seorang gay, yaitu ketika ada saudara laki-lakinya yang berkunjung dan membuat responden nyaman dengan kasih sayang dan perhatiannya di saat responden sedang ada dalam keadaan terpuruk akibat kekecewaannya terhadap perempuan. Ditambah dengan lingkungan responden yang sangat mendukungnya untuk terus membuat responden semakin tertarik pada sesama jenis. Bandura menuturkan teori yang senada, dimana keadaan lingkungan akan mempengaruhi perilaku seseorang, yang mana dapat memberikan stimulus terhadap seseorang untuk berbuat sesuatu dengan didasarkan pada apa yang mereka amati dan cermati dari lingkungannya (Hidayah, 2019: 131).

Vivienne C. Cass, seorang psikolog, mengungkapkan teori mengenai identitas homoseksual yang dikenal dengan istilah Cass' Model of Gay \& Lesbian Identity Formation. Ia mengungkapkan adanya enam tahapan perkembangan identitas homoseksual, yaitu: (1) identity confusion - kebingungan identitas, (2) identity comparison perbandingan identitas, (3) identity tolerance - toleransi identitas, (4) identity acceptance - penerimaan identitas, (5) identity pride kebanggaan identitas, (6) identity synthesis - merasa nyaman (Mastuti et al., 2012: 195).

Pada awalnya, mereka yang memiliki orientasi seksual berupa homoseksual akan mengalami kebingungan identitas, dimana mereka merasa kebingungan ketika mereka tertarik kepada sesama jenis. Lalu di tahap yang kedua, mereka akan mencoba untuk membandingkan perilakunya dengan ajaran agamanya masing-masing, serta juga dengan orang-orang disekitarnya. Dan di tahap yang ketiga, mereka akan mulai melakukan toleransi dengan mencoba 
DIEGESIS: Jurnal Teologi

Volume 6 No. 1, Februari 2021 Hlm 70-88

jujur akan keadaan diri mereka serta mencoba untuk menerima diri mereka sendiri. Di tahap yang keempat mereka akan mulai masuk ke dalam komunitas-komunitas homoseksual dan berani membuka jati dirinya terhadap teman-teman dekatnya karena mereka telah menerima keberadaan mereka sebagai seorang homoseksual. Dalam tahap yang kelima, mereka mencapai titik dimana mereka bangga dengan keadaannya sebagai seorang homoseks. Sedangkan di tahap yang keenam, mereka sudah menerima keadaan diri mereka sepenuhnya, dan menganggap stigma negatif yang dilontarkan oleh masyarakat terhadap dirinya dan kaum gay sudah tidak berlaku lagi (Mastuti et al., 2012: 196-197).

Dalam hal ini, kita dapat melihat adanya pola-pola tertentu yang membuat seseorang yang semulanya heteroseksual merubah orientasi seksualnya menjadi homoseksual, dan kemudian menerima dirinya sebagai seorang homoseksual. Hal ini dibangun atas dasar beberapa faktor, dan bukan secara alamiah. Karena pada dasarnya, sekalipun seseorang memiliki orientasi seksual berupa homoseksual sejak kecil, perlu dilihat kembali bagaimana pola asuh yang diberikan oleh orang tuanya. Sebab, sangat perlu bagi orang tua untuk memberikan peneguhan mengenai identitas seksual anak-anaknya sejak mereka kecil, agar mereka tidak mengalami identity confusion, yang kemudian akan berlanjut ke tahaptahap yang berikutnya,

\section{Sudut Pandang Biologi: Identitas}

\section{Homoseksual}

Penemuan the gay gene telah menjadi kekuatan besar yang mendukung makin banyaknya anggapan bahwa homoseksualitas adalah ciptaan Tuhan (Christina, 2016).

Dean Hamer melakukan penelitian bersama dengan rekanrekannya untuk meneliti gen yang berkaitan dengan homoseksualitas. Hamer dan rekan-rekannya meneliti 40 pasang kakak beradik yang memiliki perilaku homoseksual. Penelitiannya menghasilkan kesimpulan bahwa satu/beberapa gen yang diwariskan oleh ibu yang terletak di kromosom Xq28, memiliki kaitan dengan seseorang yang menunjukkan sifat homoseksual. Hamer pun terus melanjutkan risetnya, namun ternyata hasil 
risetnya menemukan bahwa kromosom Xq28 hanya bertanggung jawab pada sifat homoseksual pada lelaki, sedangkan pada sifat homoseksual wanita tidak berlaku. Hamer dengan jelas menyatakan dalam artikel risetnya, bahwa lokus tersebut hanya mempengaruhi variasi individual pada orientasi seksual lakilaki, namun tidak berpengaruh pada variasi individual pada orientasi seksual perempuan. Hamer pada akhirnya mengakui bahwa gen-gen bukanlah satu-satunya penentu dalam perilaku homoseksual ini, melainkan bahwa lingkungan juga memiliki peran yang besar dalam membentuk orientasi homoseksual. Dengan demikian, sebenarnya dapat disimpulkan bahwa tidak ada ungkapan yang menyatakan bahwa genetika secara murni mempengaruhi homoseksualitas. Riset Hamer ini sebenarnya dapat dikatakan gagal dalam memberi sinyal/petunjuk kuat bahwa homoseksual adalah sifat hereditas (Gozan, 2016: 76).

Kendati demikian, penemuan pertama Hamer yang berkaitan dengan homoseksual dan hereditas yang dipublikasikan pada tahun 1993 ini masih kerap kali dijadikan sebagai acuan/referensi oleh berbagai riset yang diadakan banyak orang yang pro dengan penemuan Hamer tersebut. Sebenarnya, secara tak langsung orang-orang yang memakai hasil riset Hamer dan rekan-rekannya sebagai referensi atau acuan utama seolah sedang menunjukkan bahwa homoseksual adalah sesuatu yang asli/murni, yang tidak dapat disebut sebagai penyimpangan, dan merupakan sesuatu yang tidak bisa dibereskan. Secara umum, pendefinisian diri sebagai homoseksual ini berkaitan dengan pencarian pembenaran diri, dengan cara berlindung pada payung anggapan bahwa adanya homoseksual ini disebabkan oleh faktor keturunan, yang berarti sifat genetik yang diwariskan oleh orang tua merekalah yang bertanggung jawab atas munculnya sifat dan perilaku homoseksual ini (Gozan, 2016: 77).

Rice at.al, melalui risetnya yang berfokus pada lokus Xq28, justru menunjukkan kenyataan yang bertentangan dengan penemuan lokus gen gay. Kesimpulan akhir dari penemuan Rice tidak mendukung gen X-linked sebagai dasar 
DIEGESIS: Jurnal Teologi

Volume 6 No. 1, Februari 2021 Hlm 70-88

homoseksualtias laki-laki. Tidak hanya itu, kesimpulan riset Rice ternyata juga didukung oleh beberapa penelitian mengenai potensi respon homoseksual yang dikenal dengan PHR (Potential Homosexual Response) yang dilakukan oleh peneliti-peneliti yang berbeda grup dengan Rice. Potensi respon homoseksual adalah sebuah respon yang memperlihatkan gejala atau perilaku homoseksual yang ditunjukkan oleh seseorang. Hasil riset Escofier menyatakan bahwa PHR tidak memiliki keterkaitan langsung dengan genetik, serta merupakan potensi yang di mana saja dapat terjadi (Gozan, 2016: 77).

Ternyata, sepertinya lokus Xq28 lebih besar intensitasnya untuk memiliki keterkaitan dengan penyakit mental dari pada secara khas memiliki keterkaitan terhadap perilaku homoseksual. Hubungan Xq28 dengan masalah mental ini diperkuat dengan adanya riset yang dilakukan oleh sejumlah ilmuan di Medical University of South Carolina, USA. Hasil penelitiannya menyimpulkan bahwa lokus Xq28 yang sejauh ini dianggap sebagai penanggung jawab munculnya perilaku homoseksual ternyata juga bertanggung jawab terhadap permasalahan mental. Salah satu persoalan mental yang mungkin terjadi di waktu lampau yang juga berhubungan dengan timbulnya perilaku homoseksual adalah pengalaman mereka mengenai kehangatan dan kesejahteraan orang tua mereka. Hal ini dituturkan oleh para peneliti gabungan dari beberapa lembaga di Kanada, yang mengkaji ingatan-ingatan para homoseksual. Sebanyak 524 orang dengan orientasi homoseksual dan heteroseksual ditakar responnya terhadap memorimemori akan kesejahteraan orang tua mereka dan hal lainnya yang terkait dengan kekhawatiran mereka mengenai perceraian. Dan hasilnya menunjukkan bahwa adanya hubungan yang lebih jelas antara kekhawatiran yang dialami para homoseks tersebut dengan munculnya perilaku homoseksual (Gozan, 2016: 78).

Mereka yang percaya bahwa orientasi seksual manusia dipengaruhi secara genetik tidak dapat menjelaskan secara pasti bagaimana sifat homoseksualitas dapat dipertahankan dalam populasi pada frekuensi yang cukup tinggi sedangkan faktanya adalah 
homoseksualitas justru membuat tingkat keberhasilan reproduksi mengalami penurunan. Para ahli juga banyak yang mempertanyakan bagaimana mungkin para kaum homoseksual dapat mewariskan sifat genetik yang memiliki tanggung jawab terhadap adanya perilaku homoseksual, padahal mereka tidak melakukan proses reproduksi (Gozan, 2016: 79).

Sebagian peneliti menduga adanya kemungkinan bahwa ada paparan senyawa kimia yang memiliki tanggung jawab terhadap terbentuknya perilaku homoseksualitas dalam diri seseorang. Meeker dan Ferguson merangkum penelitian para ahli mengenai adanya bahan-bahan kimia yang tersebar secara luas di masyarakat dunia dengan membuat tabel yang memuat berbagai macam zat phatalates, yang adalah zat rekaan manusia dan sangat banyak digunakan dalam perindustrian. Zatzat tersebut diperkirakan adalah hal yang menyebabkan rusaknya endokrin dan menurunnya hormon testosteron pada laki-laki. Namun, paparan senyawa kimia ini tidak memiliki sifat genetik yang kemudian diwariskan, melainkan adalah sebuah kontaminasi terhadap gen yang akan menyebabkan rusaknya atau berubahnya kualitas hormon, serta mempengaruhi perilaku yang dihasilkan. Paparan senyawa kimia yang mengakibatkan kerusakan tersebut tidak bersifat permanen dalam arti dapat diturunkan. Bahkan penelitian Theodorov et.al pada mamalia memperlihatkan bahwa ada hal yang dapat mengintervensi serta mengembalikan orientasi seksual pada mamalia kepada orientasi yang semulanya, yaitu picrotoxin perinatal (Gozan, 2016: 79-80).

Namun, tidak dapat dipungkiri bahwa ada orang-orang tertentu yang memiliki kelainan dari segi kromosomnya (genetiknya). Pada umumnya, perempuan terdiri dari kromosom XX, sedangkan lelaki terdiri dari kromosom XY. Namun demikian, ada individu-individu yang memiliki kelainan genetik, seperti Sindrom Turner $(45, \mathrm{XO})$, sindrom Trisomi/Tripel-X pada wanita (47, XXX), sindrom XYY pada pria (47, XYY), dan sindrom Klinefelter pada pria (47, XXY) (Syafitri et al., 2013). Secara biologis, kelebihan ataupun kekurangan kromosom akan 
mempengaruhi mental dan juga fisik individu. Penderita sindrom Turner yang kekurangan satu kromosom $\mathrm{X}$, memiliki gonad yang tidak berfungsi dengan baik, tidak memiliki ovarium atau uterus, memiliki tubuh yang pendek dan dadanya berukuran kecil. Penderita sindrom Tripel-X adalah perempuan yang memiliki kelebihan kromosom $\mathrm{X}$, yang ditandai dengan ciri-ciri alat kelamin dan payudaranya tidak berkembang, memiliki abnormalitas pada mental, dan menstruasi yang sangat tidak teratur. Penderita sindrom XYY adalah pria yang memiliki kelebihan kromosom $\mathrm{Y}$, yang membuat ia menjadi seorang yang agresif, suka berbuat jahat dan melanggar hukum, serta menunjukkan abnormalitas pada alat genitalia luar dan dalam. Penderita sindrom Klinefelter adalah pria yang memiliki kelebihan kromosom $\mathrm{X}$, yang menyebabkan seorang pria memiliki ciri wanita seperti tumbuhnya payudara, memiliki suara tinggi seperti wanita, ditandai dengan kecilnya testis, dan bersifat steril (Laimeheriwa, 2018: 4-7).

$$
\text { Lalu, bagaimana Alkitab }
$$
menjawab fenomena ini?

\section{Sudut Pandang Teologi: Identitas Homoseksual}

Secara jelas Alkitab menyatakan bahwa hanya ada 2 jenis kelamin, yaitu pria dan wanita. Dan itu berarti orientasi seksual yang dikehendaki Allah satu-satunya adalah heteroseksual, dimana Allah merancang agar hubungan seks dilakukan hanya di antara pria dengan wanita dan harus dalam ikatan perkawinan (Kej. 1:27; 2:18; 2:23-24; 9:20-29; Im. 18:22; Mat. 19:4-5; 19:10-12) (Marisi, 2016: 117).

$\begin{array}{cll}\text { Lalu } & \text { bagaimana } & \text { Alkitab } \\ \text { menjawab } & \text { permasalahan } & \text { biologi }\end{array}$ mengenai keberadaan orang-orang yang memiliki kelebihan atau pun kekurangan kromosom? Apakah itu menandakan bahwa Allah menciptakan mereka untuk memiliki orientasi seksual berupa homoseksual?

Menurut Marisi, Alkitab tidak memungkiri adanya individuindividu yang memiliki kelainan kelebihan atau kekurangan kromosom, seperti halnya yang dimaksud dalam Matius 19:12, yang berbunyi: "ada orang yang tidak dapat kawin karena ia memang lahir demikian dari rahim ibunya..." Marisi menyimpulkan bahwa tidak 
ada orang yang dilahirkan dengan orientasi seksual berupa homoseksual. Kecenderungan pria kemayu dan wanita tomboy memang tidak bisa dipungkiri oleh karena adanya kelainan kromosom. Hal itu dapat diterima bahkan harus diterima. Namun, dengan adanya kecenderungan seperti itu, bukan lantas berarti harus menjadi LGBT. Marisi berpendapat bahwa orangorang yang mempunyai kecenderungan tersebut harus dapat menahan diri dan meminta pertolongan Tuhan untuk dapat menjadi pribadi yang takut akan Tuhan (Marisi, 2016: 115).

Berpindah dari masalah kromosom, para teolog homoseksual membagi orang yang mempraktekkan homoseksual ke dalam dua kelompok, yaitu kelompok bawaan dan kelompok kelainan. Kelompok bawaan adalah mereka yang dilahirkan sebagai homoseks atau mereka yang dikatakan memiliki orientasi homoseksual sejak lahir (seperti pandangan mengenai gay gene). Sedangkan kelompok kelainan adalah mereka yang dilahirkan sebagai heteroseksual namun terseret ke dalam aktivitas homoseksual (Tolanda \& Ronda, 2011: 140).

Kaum Kristiani mengakui Alkitab sebagai otoritas tertinggi dalam segala hal yang memiliki hubungan dengan iman dan perilaku. Dalam Alkitab, tercatat banyak hal mengenai homoseksualitas. Alkitab tidak menggolongkan perilaku homoseksualitas sebagai bawaan dan kelainan. Alkitab secara jelas melarang homoseksualitas dan secara jelas menyatakan bahwa homoseksualitas adalah dosa dan merupakan kekejian di hadapan Allah (Tolanda \& Ronda, 2011: 140).

Kisah mengenai Sodom dan Gomora menjadi topik perbicangan yang cukup hangat di kalangan yang pro maupun yang kontra terhadap homoseksualitass. Dalam jurnalnya yang berjudul "Mendamaikan Kekristenan dan LGBT: Sebuah Upaya Hermeneutik Alkitab", Singgih menuturkan argumennya mengenai dosa Sodom dan Gomora. Singgih mempertanyakan kebenaran mengenai apakah betul bahwa orangorang yang mengepung rumah Lot dan ingin memakai kedua tamu lelakinya adalah orang-orang homoseksual. Ia menyimpulkan 
DIEGESIS: Jurnal Teologi

Volume 6 No. 1, Februari 2021 Hlm 70-88

bahwa yang menjadi penyebab

Sodom dihukum bukanlah karena

mereka berdosa dalam pengertian

bahwa mereka homoseksual, melainkan karena penduduk Sodom, yang kebanyakan heteroseksual, mau melampiaskan nafsu birahinya dengan cara memperkosa laki-laki lain secara homoseksual. Jadi, ia menyimpulkan bahwa dosa yang diperbuat oleh Sodom adalah niatan memperkosa, dimana semua niatan memperkosa adalah dosa, baik yang dilakukan oleh kaum homoseksual maupun heteroseksual (Singgih, 2020: 42).

Dari tulisan Singgih, penulis melihat bahwa secara tersirat, Singgih sedang mengatakan bahwa penduduk Sodom sebenarnya memiliki orientasi heteroseksualitas, hal ini didasarkan pada kenyataan bahwa Lot menawarkan anak perempuannya untuk "dipakai" oleh mereka. Bagi penulis, hal ini sebenarnya memperkuat bahwa Allah tidak menciptakan seseorang dengan orientasi seksual berupa homoseksual. Sejak mulanya Allah menciptakan manusia dengan jenis kelamin pria dan wanita untuk bersetubuh menjadi satu daging, dan itu berarti orientasi seksualnya berupa heteroseksual, bukan homoseksual. Hanya saja, perilaku homoseksualitas dihasilkan karena adanya penyimpangan akibat dosa, bukan karena faktor genetik dan juga bukan karena diciptakan oleh Allah. Namun, benarkah bahwa dosa Sodom hanya berbicara tentang "niatan memperkosa" saja? Apakah dosa Sodom tidak mengindikasikan pada dosa homoseksualitas?

Topik lain yang juga hangat diperbicangkan dan diperdebatkan adalah penggunaan kata "pakai" dalam Kejadian 19:5. Menurut kelompok yang pro homoseksual, mereka berargumen bahwa: kata "pakai $=>$ yada" dalam Kejadian 19:5 hanya berarti “mengetahui/berkenalan", walaupun pada tempat lain bisa berarti “berhubungan seksual". Jadi, mereka menyimpulkan bahwa dosa Sodom bukanlah dosa homoseksual, melainkan ketidakramahan (Christina, 2016).

Gunawan menyanggah hal ini, ia mengatakan bahwa adalah benar bahwa dalam Kejadian 19, orangorang Sodom mengatakan mereka ingin "yada = mengenal" dua orang tamu Lot, namun yang dimaksudkan mereka bukan hanya sekadar 
mengenal dalam pengertian pada umumnya, melainkan kata "yada" tersebut dipakai untuk memperlihatkan adanya keinginan mereka untuk melakukan hubungan seksual. Argumen ini didukung oleh beberapa fakta, yaitu bahwa (1) Lot mendorong bahkan memaksa dua orang tamunya untuk menginap di rumahnya, bisa saja Lot sudah mengetahui apa yang akan terjadi jika mereka tidak dilindungi; (2) tindakan Lot yang memberikan anak perempuannya kepada orang Sodom memperlihatkan bahwa Lot sudah mengetahui betul bahwa orang-orang Sodom menginginkan persetubuhan dengan tamu Lot, itu sebabnya Lot memberikan anak perempuannya sebagai gantinya (Gunawan, 2012: 90-91).

Lebih lanjut lagi, Gunawan mengutip Wenham, mengatakan bahwa pada saat itu, yang terjadi di kota Sodom adalah perilaku yang dipandang aneh oleh orang-orang non-Israel (bangsa kafir); orangorang yang bukan Israel sepertinya menganggap persetubuhan sesama jenis adalah hal yang biasa/umum dilakukan, namun pemerkosaan masal terhadap sesama jenis dipandang sebagai sesuatu yang tidak normal. Peristiwa Sodom ini memperlihatkan bukan saja persoalan mengenai homoseksualitas, melainkan juga pemerkosaan masal. Kedua aspek tersebut sama-sama disoroti dalam narasi tersebut (Gunawan, 2012: 91).

Secara keseluruhan, jika kita lihat, pendapat Singgih mengenai orang-orang Sodom yang memiliki orientasi heteroseksual adalah benar dan tidak dipersalahkan. Hal ini justru memperjelas bahwa Allah tidak menciptakan seseorang dalam keadaan orientasi homoseksualitas. Adalah benar bahwa Sodom dihukum karena niatan pemerkosaan massalnya, tapi adalah benar juga bahwa orang-orang Sodom juga memiliki dosa "perilaku homoseksualitas", terbukti dengan mereka mau berhubungan seksual dengan dua orang pria, tamu Lot.

\section{Sikap terhadap Homoseksual}

Perlu kita pahami, seorang homoseksual bukanlah seseorang yang sakit atau tidak normal, melainkan seorang yang berdosa; itu sebabnya, jalan keluar yang utama dari permasalahan homoseksual ini 
adalah pertobatan, bukan hanya sekadar pemulihan dalam hal psikologi dan sosial. Kaum homoseksual perlu bahkan harus mengetahui, bahwa dalam Kristus mereka akan mendapatkan anugerah keselamatan yang akan memperbaharui mereka. Menurut Gunawan, sekalipun ada seorang Kristen yang oleh karena pengalaman di masa lampau yang begitu traumatis lalu memiliki orientasi seksual yang menyimpang, orang tersebut pasti akan berusaha untuk menangkal dan meninggalkannya, sebab ia mengerti betul bahwa hal itu adalah dosa dan merupakan kekejian di mata Tuhan (Gunawan, 2012: 113).

Gereja perlu memiliki sikap yang jelas terhadap homoseksualitas. Gereja tidak boleh menjadi lembaga yang permisif, namun juga tidak boleh menjadi lembaga yang fobia dengan homoseksualitas. John Stott, seperti yang dikutip oleh Gunawan, menulis, "Betapa membingungkan dan menyakitkan pun dilemma mengenai homoseksual ini bagi paham Kristiani kita, Yesus Kristus juga tetap menawarkan kepada kita semua tanpa terkecuali (termasuk para kaum homoseksual), iman, pengharapan, dan kasih..."
(Gunawan, 2012: 114). Seberapa keras pun kita menolak aksi-aksi homoseksual, namun kita tidak boleh mendehumanisasikan mereka yang terlibat di dalamya (Sipayung \& Sihombing, 2018: 339).

Way of thinking yang sangat baik diutarakan oleh Davis; ia mengatakan bahwa kita tidak bisa memberikan support kepada hal yang membela sesuatu yang secara moral salah. Menjadi seorang homoseksual memang adalah sebuah kebebasan manusia (Gunawan, 2012: 115). Karena dosa, manusia telah menggunakan kehendak bebasnya secara keliru, yang digunakan secara sewenang-wenang, padahal seharusnya digunakan dengan bertanggung jawab (Misi et al., 2020: 25). Kita perlu menyadari bahwa kebebasan yang kita sebagai manusia miliki bukanlah kebebasan yang tidak ada batasan. Kebebasan manusia adalah kebebasan yang harus dipertanggungjawabkan di hadapan Tuhan kelak (Gunawan, 2012: 115).

Sebagai gereja, kita perlu melihat kembali ke dalam Alkitab, yang mana Alkitab dengan jelas mengecam tindakan praktik homoseksual. Dalam Roma 1:26-27, Paulus dengan jelas mengecam praktek homoseksual 
yang sama dengan penyembahan berhala, yang berakar pada satu masalah utama, yaitu penolakan terhadap Allah. Itu berarti, gereja juga harus berada pada posisi yang sama dengan Alkitab, yaitu mengecam tindakan praktik homoseksual (Saputra, 2016: 109).

Gereja perlu mengambil sikap yang tegas, di mana gereja tidak memperbolehkan adanya pemberkatan pernikahan, karena pernikahan homoseksual adalah pernikahan yang tidak dikehendaki oleh Allah.

Justru sebaliknya, gereja harus menentang pernikahan homoseksual karena tidak sesuai dengan kehendak Allah. Namun di sisi lain, gereja harus mengasihi orang-orang yang terlibat dalam praktik-praktik homoseksual, gereja perlu dan bahkan harus untuk merangkul serta menolong mereka supaya mereka terlepas dari keterikatan homoseksual dengan cara memberikan perhatian dari aspek sosial-psikologis dan juga terlebih lagi spiritual. Gereja dapat juga mengambil tindakan untuk memberikan konseling dan juga pembinaan secara rohani untuk setiap pribadi yang bergumul dengan hal- hal yang berbau homoseksualitas (Tolanda \& Ronda, 2011: 153-157). Penerimaan tetaplah hal utama yang dibutuhkan bagi gereja dalam menghadapi maraknya praktik homoseksual. Menerima orangnya namun menolak dosanya adalah hal yang Yesus lakukan yang seharusnya juga gereja lakukan.

\section{SIMPULAN DAN REKOMENDASI}

Tuhan tidak pernah menciptakan seseorang dengan orientasi homoseksual. Identitas homoseksual sebenarnya bukanlah diciptakan oleh Tuhan, melainkan lahir karena adanya dosa, yang membuat manusia melakukan berbagai macam penyimpangan (termasuk salah satunya homoseksualitas). Bahkan secara genetik, homoseksual tidaklah diwariskan. Homoseksual tidak memiliki keterkaitan dengan gen.

Adanya "gay gene" hanya merupakan argumen yang dibangun dunia untuk berlindung dibawah penyerahan diri terhadap dosa. Gay gene hanyalah argumen yang berusaha untuk menipu manusia agar manusia tidak dapat pulih dan tidak dapat hidup kudus di hadapan Allah. Padahal kenyataannya, Allah tidak 
menciptakan gay gene, itu merupakan manipulasi yang iblis coba bangun di tengah-tengah manusia.

Pada intinya, homoseksualitas adalah dosa dan merupakan kekejian di hadapan Allah, hal ini dikarenakan homoseksualitas adalah penyimpangan dari segala sesuatu yang telah dijadikan Allah sejak mulanya. Segala sesuatu yang melenceng dari apa yang Allah kehendaki adalah dosa. Frank Worthen mengatakan bahwa ketika seseorang melakukan praktek homoseksual, maka dapat disimpulkan bahwa ia sedang mengalami kerusakan dalam dirinya berkaitan dengan gambar Allah, gambar diri sendiri, dan gambar orang lain (Jatmiko, 2019: 34).

Oleh karena itu, penanganan terbaik untuk para kaum homoseksual adalah dengan cara bertobat. Para kaum homoseksual pertama-tama harus membuka pikirannya, dan belajar untuk menerima fakta bahwa mereka tidak dilahirkan dan mereka tidak tercipta dalam keadaan seperti itu. Mereka perlu sadar betul bahwa itu merupakan pekerjaan Iblis untuk memanipulasi mereka agar mereka tidak dapat hidup berkenan kepada Allah.
Iblis dapat memakai setiap trauma-trauma masa lalu, dan lingkungan serta media apapun untuk membuat manusia melenceng dari kehendak Allah. Demikian juga Iblis memakai hal-hal tersebut untuk membuat manusia memiliki penyimpangan orientasi seksual. Itu sebabnya, para kaum homoseksual perlu menanamkan fakta bahwa mereka bukan diciptakan dengan orientasi homoseksual, melainkan Iblislah yang menyebabkan hal itu dengan cara menggunakan berbagai faktor sebagai alatnya.

Selanjutnya, para kaum homoseksual perlu untuk datang kepada Kristus, mengakui dosanya, merendahkan hatinya untuk mengakui ketidakberdayaannya untuk menolak dosa, serta meminta kasih karunia Allah agar mereka dimampukan untuk menolak dosa homoseksual. Mereka perlu minta belas kasihan Tuhan, dan mereka perlu berjuang untuk menolak dosa homoseksual. Sekalipun jika tidak pulih $100 \%$, perjuangan menolak dosa homoseksual adalah hal yang harus terus dilakukan demi memiliki hidup yang berkenan kepada Allah.

Orang tua juga harus ikut ambil bagian dalam hal ini. Bagaimana pun 
juga, orang tua memiliki peran yang sangat penting dalam memberikan pola asuh yang benar sesuai dengan yang Alkitab ajarkan. Orang tua harus memberikan peneguhan terhadap identitas seksual masing-masing anak sesuai dengan kodratnya masingmasing. Seperti yang dikatakan oleh Benyamin, bahwa keluarga memiliki fungsi edukatif, di mana orang tua harus menjadi alat/sarana yang pertama kali memberikan unsur pendidikan kepada anak (Benyamin, 2020: 19), termasuk salah satunya mengenai penegasan identitas seksual.

Gereja juga perlu mengambil sikap yang jelas mengenai perihal homoseksual, di mana gereja perlu untuk tetap berpegang pada Alkitab sebagai patokan mengenai bagaimana gereja harus bersikap, serta berfungsi secara maksimal untuk berperan dalam menangani persoalan homoseksual terutama di dalam gereja (orang-orang Kristen). Gereja tidak boleh lupa akan tugas kehadirannya di dunia ini, yaitu sebagai agen pemulihan dan untuk melaksanakan Amanat Agung Tuhan Yesus Kristus dengan membawa seruan pertobatan dan kabar keselamatan kepada setiap orang, termasuk di dalamnya para kaum homoseks.

\section{DAFTAR PUSTAKA}

Benyamin, P. I. (2020). Peran Keluarga dalam Pendidikan Anak pada Masa Pandemi Covid-19. KHARISMATA: Jurnal Teologi Pantekosta, 3(1), 13-24. https://doi.org/10.47167/kharis. v3i1.43

Christina, E. (2016). Pandangan Alkitab dan Medis Terhadap Perilaku LGBT. Jurnal Berea.

Gozan, M. (2016). Perilaku Homoseksual:Mencari Akar Rumput Pada Faktor Genetik. Nizham, 5(1), The study based on literatures on this article pre.

Gunawan, C. (2012). Dapatkah Perilaku Homoseksual Diterima? Jurnal Amanat Agung, 8(1), 85-115.

Hasnah, H., \& Alang, S. (2019). Lesbian, Gay, Biseksual Dan Transgender (LGBT) Versus Kesehatan: Studi Etnografi. Jurnal Kesehatan, 12(1), 63-72. https://doi.org/10.24252/kesehat an.v12i1.9219 
Hidayah, F. (2019). Dinamika

Orientasi Seksual pada Kaum

Gay. Psikologia: Jurnal

Psikologi, $\quad 2(2), \quad 117$. https://doi.org/10.21070/psikolo gia.v2i2.1549

Jatmiko, B. (2019). Hakekat Seksualitas Manusia : Perspektif Gereja Kristen Nazarene di Abad 21 terhadap Praktek LGBT. Sanctum Domine: Jurnal Teologi, 4(1), 29-39. https://doi.org/10.46495/sdjt.v4i 1.15

Laimeheriwa, B. M. (2018). Variasi Dan Sindrome Kromosom. Https://Www.Researchgate.Net. https://doi.org/DOI: 10.13140/RG.2.2.35393.04964

Marisi, C. G. (2016). Perspektif Alkitabiah Terhadap Gerakan LGBT. Real Didache, 1(1), 109122.

Mastuti, R. E., Winarno, R. D., \& Hastuti, L. W. (2012). Pembentukan Identitas Orientasi Seksual Pada Remaja Gay. Prediksi, 194. http://journal.unika.ac.id/index. $\mathrm{php} / \mathrm{pre} / \mathrm{article} / \mathrm{view} / 271$

Mirzaqon, A. (2018). Studi Kepustakaan Mengenai Landasan Teori Dan Praktik
Konseling Expressive Writing Library. Jurnal BK UNESA, 1, 1-8.

Misi, K., Dalam, K., Perjanjian, P., \& Pakpahan, G. K. R. (2020). KARAKTERISTIK MISI KELUARGA DALAM PERSPEKTIF PERJANJIAN

LAMA. Vox Dei, 1(1), 16-36.

Rahardjo, W. (2007). Sikap Akan Respon Terhadap Identitas Sosial Negatif Dan

Pengungkapan Orientasi Seks Pada Gay. Jurnal Ilmiah Psikologi Gunadarma, 1(1), 9096.

Saputra, B. E. (2016). Pengaruh Presuposisi Homoseksual Dalam Membaca Alkitab (Sebuah Studi Terhadap Penafsiran Kaum Revisionis Atas Roma 1:26-27). Jurnal Theologi Aletheia Vol. 18 No. 11 September 2016, 18(11), 88. Singgih, E. G. (2020). Mendamaikan Kekristenan dan LGBT: Sebuah Upaya Hermeneutik Alkitab. Jurnal Ledalero, 19(1), 34-54. Sipayung, T., \& Sihombing, R. (2018). LGBT DARI SUDUT PANDANG TEOLOGI KRISTEN Tumini Sipayung 
Roma Sihombing. BISMAN

INFO, 5(1), 335-344.

Syafitri, K., Auerkari, E., \& Suhartono, W. (2013). Metode

pemeriksaan jenis kelamin

melalui analisis histologis dan DNA dalam identifikasi odontologi forensik (Sex determination using histological and DNA analysis in forensic odontology). Pdgi, 62(1), 11-16. http://staff.ui.ac.id/system/files/ users/elza.ibrahim/publication/5 9-188-1-pb_ks_eia.pdf

Tolanda, Y., \& Ronda, D. (2011). Tinjauan Etika Kristen Terhadap Homoseksualitas. Jurnal Jaffray, 9(1), 131-163. https://doi.org/10.25278/jj71.v9i 1.88

Veritasia, M. . (2014). Pengungkapan Informasi Privat Tentang Identitas Seksual Seorang Gay Kepada Orang Lain. Commonline Departemen Komunikasi, 4(2), 273-286. 